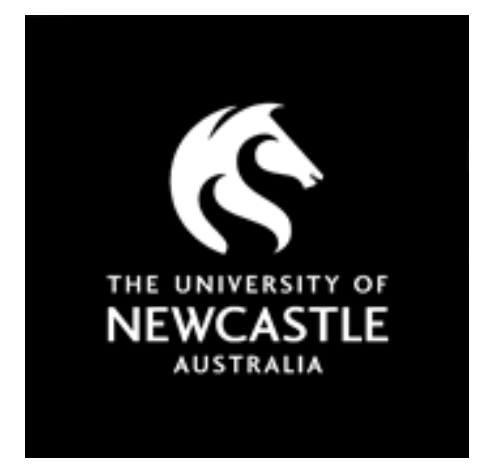

\title{
NOVA
}

University of Newcastle Research Online

nova.newcastle.edu.au

Scott, Hayley A.; Jensen, Megan E.; Wood, Lisa G. "Dietary interventions in asthma", Current Pharmaceutical Design Vol. 20, Issue 6, p. 1003-1010 (2014)

Available from: http://dx.doi.org/10.2174/13816128113190990421

Accessed from: http://hdl.handle.net/1959.13/1296132 


\section{Dietary interventions in asthma}

Hayley A Scott ${ }^{1,2}$, Megan E Jensen ${ }^{1,2}$, Lisa G Wood ${ }^{1,2}$.

${ }^{1}$ Respiratory and Sleep Medicine, Hunter Medical Research Institute, John Hunter Hospital, Newcastle, NSW Australia 2305.

${ }^{2}$ Centre for Asthma and Respiratory Diseases, The University of Newcastle, NSW Australia 2308.

\section{Corresponding Author:}

Dr Lisa Wood,

Centre for Asthma and Respiratory Diseases, HMRI, Level 2, Locked Bag 1, Hunter Region Mail Centre, NSW, 2310, Australia

Phone: +61240420147

Fax: +61240420022

e-mail: Lisa.Wood@newcastle.edu.au 


\section{ABSTRACT:}

Asthma is a chronic inflammatory disorder of the airways. The inflammatory response in asthma is heterogeneous. Allergen specific responses lead to activation of the acquired immune system, via a predominantly IL-5 mediated, eosinophilic pathway. Stimuli such as viruses and bacteria activate the innate immune system, via a predominantly IL-8 mediated, neutrophilic pathway. Asthma has also been demonstrated to involve a systemic inflammatory component.

Glucocorticoids are the predominant pharmacological treatment used to control inflammation in asthma. However, compliance with medications can be compromised due to patient concerns about side effects. Hence dietary interventions that target the inflammatory response in asthma have great potential.

Various aspects of dietary intake are known to modulate inflammation. Saturated fatty acids can induce an inflammatory response via activation of pattern recognition receptors. Omega-3 fatty acids can be anti-inflammatory, via mechanisms such as modification of eicosanoid production. Antioxidants can have anti-inflammatory effects as they scavenge free radicals, preventing activation

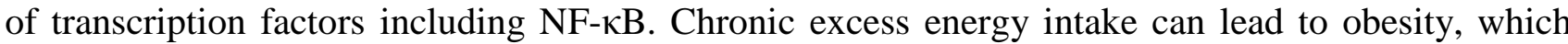
augments inflammation due to the release of inflammatory mediators by adipose tissue. Here we review the role of these dietary components in asthma.

Key Words: asthma, antioxidants, fatty acids, obesity, inflammation 


\section{INTRODUCTION}

Asthma is a respiratory disease characterised by variable airflow obstruction that is often reversible, mucus hypersecretion and airway hyperresponsiveness (AHR) [1]. Asthma involves an inappropriate triggering of the $\mathrm{T}$ helper (Th)2 immune response, leading to interleukin (IL)-5 mediated eosinophilic airway inflammation and the hallmark symptoms of asthma: wheeze, shortness of breath, cough, sputum production and chest tightness [2]. Inhaled allergens trigger this response, causing the release of histamine, leukotrienes (LT) and the Th2 cytokines IL-4, IL-5 and IL-13 [3]. IL-5 stimulates the infiltration and activation of eosinophils, which cause damage to respiratory epithelial tissue [3]. This dysregulated Th2 response leads to an eosinophilic pattern of airway inflammation in some individuals. There is also evidence of a neutrophilic pattern of airway inflammation, characterised by a persistence of asthma symptoms and AHR in the absence of airway eosinophilia [4]. Neutrophilic asthma is generally characterised by an older, non-atopic, predominantly female population who exhibit less airway reactivity and a later onset of disease [4]. Environmental exposures such as pollutants, ozone, viruses and bacterial endotoxins induce neutrophilic airway inflammation and airway obstruction [2]. Increased levels of toll-like receptor (TLR) 4 and TLR2 in the sputum of those with neutrophilic asthma, compared with other asthma inflammatory phenotypes, indicate that the innate immune response is involved [5]. Lipopolysaccharide (LPS) may be involved in the aetiology of neutrophilic asthma, which activates TLRs, leading to the release of the proinflammatory mediators IL-8, tumour necrosis factor-alpha (TNF- $\alpha$ ) and IL-1 $\beta$ [5], which attract neutrophils to the site of inflammation in the airways [6].

An increase in systemic inflammation is also observed in asthma [7]. Recently, we demonstrated that plasma IL-6 and C-reactive protein (CRP) are elevated in adults with neutrophilic asthma compared with non-neutropilic asthma [8]. We have also demonstrated IL-6 is associated with poorer lung function and asthma control, and sputum neutrophilia [9]. An obese murine model demonstrated reduced AHR following administration of IL-6 antibodies [10], while IL-6 deficient mice exposed to 
ozone have reduced airway neutrophils [11]. There is also evidence of increased systemic inflammation in children with asthma. Serum/ plasma levels of TNF- $\alpha$, LTB4, and thromboxane (TX)A2 have been found to be 5.6, 7.2 and 11 times higher, respectively, in the alveolar macrophages of infants with wheeze compared to infants without wheeze [12]. Elevated circulating levels of TNF- $\alpha$ and TNF receptor-1 and receptor-2 have also been documented in children and adults with AHR, compared to those without AHR and found to negatively correlate with $\mathrm{FEV}_{1}[13]$. These studies suggest that systemic inflammatory mediators may be important to airway responses in both adults and children with asthma.

Pharmacological management of asthma predominantly involves the use of inhaled corticosteroids (ICS) for prevention of symptoms, which are effective in reducing eosinophilic airway inflammation. However, there is emerging evidence that ICS are less effective in obese adults [14] and children [15]. Bronchodilators are also commonly used for relief of symptoms. Wood et al, have recently shown that the efficacy of $\beta_{2}$-agonists, is reduced after a high fat meal [16]. Evidence suggests that dietary interventions to either reduce energy stores (reduce obesity) or reduce intake of saturated fat in targeted patients may improve responsiveness to current asthma therapy.

Asthma incidence has increased in western countries [17] and in those migrating from a developing to a westernised country [18], suggesting that features of a western lifestyle may be implicated in the development and progression of asthma. Epidemiological studies support this hypothesis; westernstyle fast food intake has been shown to increase asthma risk in children [19, 20], consumption of a diet high in 'western’ foods versus ‘asian’ foods has been associated with increased asthma risk [21] and a diet high in fast foods, has been associated with increased childhood asthma prevalence [22]. Typical of westernisation is a dietary pattern consisting of a high intake of dietary fat, particularly saturated fat and an elevated omega-6:omega-3 ratio; a low antioxidant intake; and chronic metabolic surplus leading to obesity [23]. Conversely, Asian and Mediterranean dietary patterns are typically low in animal products and high in whole grains and vegetables [24]. This paper will discuss the 
scientific and epidemiological evidence supporting the role of dietary intervention in both the management and prevention of asthma.

\section{Dietary Fat and Asthma}

As part of the normal response to a high fat meal, circulating fatty acids increase and are then utilised to meet the energy needs of the host. Excess fatty acids are incorporated into triacylglycerols, undergo lipogenesis and are stored [25]. However, fat intake exceeding the saturation point of both these pathways induces a lipotoxic state, causing activation of inflammatory pathways and oxidative stress, resulting in 'postprandial metabolic inflammation' [26]. This includes the release of NF- $\kappa \mathrm{B}$ and increased concentrations of IL-6 and CRP [16, 27]. These inflammatory changes occur within one hour postprandially and are sustained for at least three hours [16]. Therefore, constant exposure to a high fat diet results in a maladaptive response, leading to sustained systemic inflammation and oxidative stress. Both the quality and quantity of fat appear important in determining the postprandial inflammatory response. A number of studies have examined asthma risk in relation to the quantity of fat in the diet. For example, a 10\% increase in dietary fat intake has been shown to increase the risk of asthma development by $70 \%$ in men [28]. In another study in school-aged children, increased percentage energy derived from fat intake was associated with an increased odds of current asthma [29]. Quantity of dietary fat intake has also been linked with increased odds of AHR [30] and asthma severity [31].

\section{Saturated Fatty Acids and Asthma}

Saturated fatty acids activate TLR4 and TLR2, resulting in the activation of NF- $\mathrm{BB}$ and upregulation of the proinflammatory cytokines IL-6, IL-8 and TNF- $\alpha$ [32, 33]. Indeed, interventional studies show that in healthy populations a high saturated fatty acid intake is associated with increases in CRP, IL6, TNF- $\alpha$ and NF- $\kappa \mathrm{B}$ activity $[34,35]$. However, there is limited data in the asthmatic population. 
Saturated fat intake increases the risk of current asthma in adolescents [36] and is associated with increased odds of AHR in young adults [30]. Self-reported dietary data in 638 Spanish schoolchildren demonstrates that intake of saturated fatty acids is associated with increased odds of current asthma [29]. Recently, Wood et al [16] found that a meal high in saturated fat was associated with suppressed bronchodilator response and increased sputum neutrophils and TLR4 micro (m)RNA in asthmatic adults. Additionally, in a cross-sectional population of asthmatic males, plasma saturated fatty acids were positively correlated with sputum neutrophils [9]. In contrast, other studies have found no association between saturated fatty acid intake and current asthma [37].

\section{Polyunsaturated Fatty Acids and Asthma}

The manipulation of dietary polyunsaturated fat modifies the pattern of inflammation by changing the composition of cellular membranes, leading to alterations in eicosanoid and prostaglandin synthesis [38]. Linoleic acid is an omega-6 polyunsaturated fatty acid (PUFA) that is converted to arachidonic acid in the body, and then to the proinflammatory eicosanoids $\mathrm{LTB}_{4}$ and prostaglandin $(\mathrm{PG}) \mathrm{E}_{2}$ [38]. $\mathrm{LTB}_{4}$ enhances natural killer activity, is a neutrophil chemoattractant and increases the production of the Th1 cytokines TNF- $\alpha$, IL-2, IL-6 and interferon (IFN)- $\gamma$ [38]. Since dietary intake of omega-6 is high in a Western diet, there is a high concentration of this proinflammatory class of fatty acids incorporated into cellular membranes [39]. Omega-3 fatty acids actively compete with omega-6 for incorporation into cellular membranes. Increased intake of omega-3 fatty acids reduces arachidonic acid (AA) content of cellular membranes, and increases eicosapentaenoic acid (EPA) and docosohexaenoic acid (DHA) content. The presence of omega-3 fatty acids inhibits the conversion of $\mathrm{AA}$ to $\mathrm{PGE}_{2}$, resulting in the production of $\mathrm{PGE}_{3}$ and $\mathrm{LTB}_{5}$, which are far less biologically active [39]. As a result, omega-3 fatty acids are considered to be anti-inflammatory. 
The effect of omega- 6 fatty acids has been examined extensively in asthmatic populations. A number of studies have quantified omega- 6 intake by dietary questionnaire and found no associated risk of current asthma [36, 40]. However, the majority of studies that directly quantified fatty acid concentration suggest omega-6 fatty acids modify asthma risk and severity. For example, in a population of 526 children aged 8-11 years, AA concentration of serum cholesterol esters was associated with increased odds of current asthma and wheeze, while the odds of frequent asthma attacks was increased by 5.5 fold in the highest compared with the lowest quartile of AA [41]. Woods et al. [37] found total plasma omega-6 concentration in adults was associated with bronchial reactivity, but not with asthma diagnosis or atopy. Conversely, in another study, increased linoleic acid (an omega-6 fatty acid) concentration in the erythrocyte membrane was associated with reduced odds of asthma [42].

Several studies have reported that intake of omega-3 fatty acids or fish is associated with improved lung function [43, 44] and decreased risk of asthma [45-51], AHR [47, 48] and wheeze [50]. Conversely, there are also studies which don't support, or only partially support, this hypothesis [44, 52-59]. Similarly, data examining the possible benefits of dietary omega-3 fatty acid supplementation in asthma are heterogeneous. There is little evidence to suggest that omega-3 fatty acids are beneficial in established asthma, as summarized by a 2002 Cochrane review [60]. However, several studies have reported fish consumption, rather than purified EPA/DHA, to be protective against the development of asthma, particularly in childhood [47-51, 61]. One recent study found introducing fish to infants between the ages of 6 and 12 months is associated with a lower prevalence of wheeze at 4 years of age, compared with those infants who were introduced to fish either before or after this age [62]. It is also possible that different forms of marine oils in the diet may have varying effects on immune responses, due to the presence of a variety of lipid mediators, as well as different quantities of omega-3 fatty acids. For example, in an animal model of allergic asthma, a marine extract from green lipped mussels, but not purified fish oil, was shown to reduce Th2 cytokine 
responses, eosinophil influx, mucus hypersecertion and AHR [63]. In a human trial, daily supplementation with this same marine extract decreased daytime wheeze and exhaled hydrogen peroxide concentration in a randomized controlled trial [64]. These data support the hypothesis that whole foods, rather than individual nutrients, may be most beneficial.

\section{Monounsaturated Fatty Acids and Asthma}

In in vivo models demonstrate monounsaturated fatty acids (MUFA) inhibit TLR4 and TLR2

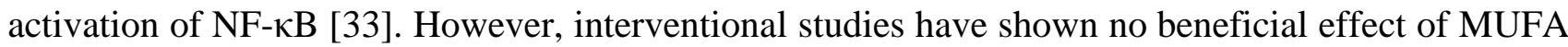
on circulating inflammatory marker s[65], suggesting that MUFA alone may in fact be neutral in terms of inflammation in humans. Few studies have examined the effect of MUFA specifically in relation to asthma. Huang and Pan [36] found an inverse association between reported MUFA intake and asthma risk in female adolescents. Scott et al. [9] recently found an inverse association between plasma MUFA and neutrophilic airway inflammation in asthmatic men. However, others have found no effect of MUFA on current asthma [40, 41, 66, 67], lung function [41], atopy [37] or wheeze [40].

\section{Antioxidants and Asthma}

Reactive oxygen species (ROS) are produced as part of normal cellular activities, such as respiration, and have an important role in cellular signalling and homeostasis. ROS are highly reactive, with excessive formation causing cellular damage to DNA, proteins, lipids and polysaccharides. Excess ROS in the airways induce airway inflammation [68], AHR [68, 69] and mucin secretion [68]. This creates a positive feedback loop, whereby airway inflammatory cells further contribute to increased oxidative stress in the airways. Antigen challenge in allergic individuals results in the spontaneous production of ROS by airway eosinophils [70]. Furthermore, circulating eosinophils, neutrophils and monocytes from asthmatics have a greater production of ROS compared with cells from nonasthmatics [71]. Therefore, both the airway and systemic inflammatory changes occurring in asthma appear to contribute to oxidative stress, resulting in antioxidant depletion and consequently an 
oxidant-antioxidant imbalance. Asthmatics appear to have low antioxidant levels in the airways compared with healthy subjects, independent of an adequate antioxidant intake [72]. Antioxidant intake appears to protect against asthma development [73], likely due to its role in maintaining oxidant-antioxidant balance, thus preventing oxidative damage. Children with asthma have a lower total antioxidant capacity (TAC), while malondialdehyde (MDA, a marker of lipid peroxidation) has been correlated with exhaled nitric oxide (eNO) concentration [74], thus suggesting oxidative stress and allergic airway inflammation modify antioxidant activity in asthmatic children.

Exogenous antioxidants, including ascorbic acid, carotenoids, flavonoids and tocopherols, assist in maintaining cellular equilibrium and preventing cellular damage by neutralising ROS. Dietary fruits and vegetables are the primary source of exogenous antioxidants, and the decline in fruit and vegetable intake in Western society, resulting in a shift in oxidant-antioxidant balance, has been hypothesised to have contributed to the recent rise in asthma prevalence [75]. Indeed, intake of whole fruits and vegetables has been linked with respiratory outcomes and asthma development. For example, children who reported eating fruit more than once a day had a forced expiratory volume in 1 second $\left(\mathrm{FEV}_{1}\right)$ that was $79 \mathrm{~mL}$ higher than children who reported never eating fruit [76]. Over a seven year period, adults who had the greatest reduction to their fresh fruit intake had a decline in $\mathrm{FEV}_{1}$ of $107 \mathrm{~mL}$ when compared with adults who maintained their fruit intake [77]. In a recent 3 month randomised controlled trial in adults with asthma, a high fruit and vegetable intake $(\geq 5$ serves of vegetables and $\geq 2$ serves of fruit per day) was shown to decrease the risk of asthma exacerbation by 2.2 fold, compared to a low fruit and vegetable intake ( $\leq 2$ serves of vegetables and $\leq 1$ serve of fruit per day). An increase in plasma CRP was also reported in the low fruit and vegetable group [78].

\section{Carotenoids and Asthma}


Carotenoids, which are primarily found in fruit and vegetables, have potent antioxidant properties. Two large epidemiological studies have shown that higher plasma carotenoid levels slow age-related lung function decline $[79,80]$. In addition, a number of cross-sectional studies have demonstrated that self-reported dietary intake of carotenoids is linked with better respiratory function in both adults and children [81, 82]. $\beta$-carotene and $\alpha$-carotene have been linked with a $15 \%$ and $10 \%$ reduced risk of asthma development in children, respectively [83, 84]. In adults with asthma, Wood et al. [85] demonstrated that a ten day low antioxidant diet resulted in a significant reduction in plasma carotenoid concentrations, associated with an increase in sputum neutrophil concentration and a significant deterioration in $\mathrm{FEV}_{1}$, forced vital capacity (FVC) and asthma control. Hazlewood et al. [86] supplemented OVA-sensitised mice with tomato extract, rich in lycopene, for 14 days and demonstrated a significant reduction in eosinophil, IL-5 and IL-4 influx into the airways. Retinol, which can be derived from $\beta$-carotene, has also been investigated in a small number of studies [8789]. A randomised controlled trial in chronically malnourished pregnant women found the offspring of mothers supplemented with Vitamin A had a $46 \mathrm{~mL}$ higher $\mathrm{FEV}_{1}$ and FVC at age 9-13 years, compared with the offspring of mothers who received the placebo [87].

\section{Vitamin C and Asthma}

Vitamin C acts as an electron donor to ROS and is the most abundant antioxidant in the airway lining fluid [90]. Vitamin C may reduce the risk of asthma development in both adults [91] and children [84] and increased intake has been associated with better lung function [88]. Low vitamin C levels have been associated with increased bronchial reactivity to methacholine [30]. There is evidence to suggest that subjects regularly exposed to ozone may particularly benefit from vitamin C intake [92, 93]. Indeed, guinea pigs treated with vitamin $C$ for 26 days have a reduced influx of eosinophils and neutrophils into the airways after OVA-challenge [94]. A randomised cross-over trial in children demonstrated that a six week supplementation with either vitamin $C$, zinc or omega-3 fish oil, was 
associated with improvements in asthma control, $\mathrm{FEV}_{1}$ and $\mathrm{FEV}_{1} / \mathrm{FVC}$, and a reduction in sputum eosinophils [95]. Despite numerous studies suggesting potential benefit of vitamin C in relation to airway responses, a recent Cochrane review concluded that there was insufficient evidence to recommend a specific role for vitamin $\mathrm{C}$ in the treatment of asthma, largely due to a lack of methodologically strong and large-scale randomised controlled trials [96].

\section{Vitamin E and Asthma}

Vitamin E prevents autoxidation of lipids and converts ROS to less active forms [23]. Vitamin E includes four tocopherols and four tocotrienols, and is associated with improved asthma control [97], reduced wheeze $[98,99]$ and better lung function [82]. A higher maternal intake of vitamin E reduces asthma risk in offspring at five years of age [99] and wheeze at age two years [100]. Furthermore, vitamin $\mathrm{E}$ intake is associated with lower serum $\operatorname{Ig}($ Immunoglobulin)E concentration and lower allergic sensitisation [101]. This is supported by murine models, demonstrating an attenuated IgEmediated immune response after vitamin E supplementation [102, 103]. After intranasal OVAchallenge, Wagner et al. [104] demonstrated a 74\% reduction in airway eosinophils and significant reductions in the nasal expression of IL-5 and IL-13, in rats treated with $\gamma$-tocopherol for four days. Nonetheless, a randomized control trial of vitamin E supplementation for asthma in adults, showed no evidence of clinical benefit [105].

\section{Obesity and Asthma}

Obesity is a risk factor for asthma, with obesity doubling the risk of asthma development in adults [106], and increasing risk of asthma in school aged children by 1.5 times [107]. Obese asthmatic adults experience more severe asthma symptoms, increased emergency room visits and hospitalisations, and poorer lung function, compared with asthmatics within the healthy weight range [108, 109]. Similarly, obese children experience more severe asthma, as supported by two recent analyses of large cohorts which reported an association between increased BMI and/ or adiposity in 
children and increased asthma symptoms, asthma exacerbations and emergency department presentations $[110,111]$. In adults, abdominal obesity is associated with a greater risk of nonallergic, but not allergic, asthma [112] and the association appears to be stronger in females [113, 114]. In children, the association between obesity and asthma appears to exist in both the absence and presence of allergy, however, evidence suggests the obese-asthma association may be stronger in allergic children [115]. While there is clear evidence supporting an association between obesity and asthma outcomes, evidence suggesting mechanisms is less clear. Various hypotheses have been proposed including mechanical effects [116, 117], inflammation [9, 118] and hormones [119, 120].

\section{Mechanical Effects of Obesity}

Obesity is associated with increased breathlessness independent of asthma, believed to be the result of adipose tissue within the android and thoracic regions exerting a direct effect on the chest wall and downward movement of the diaphragm [116].

\section{Inflammatory Effects of Obesity}

Both obesity and asthma involve a low-grade systemic inflammation, and it has been suggested that obesity-induced inflammation may drive the development and progression of asthma in susceptible individuals. It is clear that the typical Th2 inflammatory response is not responsible, as several studies have found no association between obesity and eosinophilic airway inflammation [121, 122] or eNO [111, 122] in adults or children. Higher levels of systemic leukocytes, neutrophils and platelets have been documented in obese asthmatic children compared with those of a healthy weight[123], although there is no evidence of alterated airway inflammation [124]. Evidence of an inverse association between obesity and both sputum eosinophilia [125] and eNO [125, 126] in adults suggests obesity may actually produce a shift away from the Th2 response in adult asthma. Neutrophilic inflammation is Th1 driven and has also been recently examined as a potential driver of 
the obese-asthma phenotype. Scott et al.[9] found a positive association between BMI and airway neutrophilia and BMI in females, and others have since found a similar association between BMI and neutrophils in adults, both in the airways [127] and circulation [127, 128].

\section{Effects of Obesity-Related Hormones}

Adipokines, hormones released by adipose tissue, may have a role in driving the association between obesity and asthma as they are biologically active and their receptors are widely distributed throughout the body, including the lungs. Leptin and resistin are increased in obesity and also in asthma, independent of BMI [129-132]. They have pro-inflammatory effects, including activation of NF-кB [133, 134], upregulation of TNFa levels [135, 136] and enhancement of neutrophil function [133, 137]. In animal models it has been shown that exogenous leptin administration enhances airway inflammation [138] and AHR [139]. Adiponectin, on the other hand, generally acts as an antiinflammatory hormone and is reduced in obesity [140], most likely due to the production of TNF- $\alpha$ and IL-6 by adipose tissue-resident macrophages, which inhibits adipocyte production of adiponectin [141]. Adiponectin negatively regulates TLR signaling pathways [142], inhibits NF-кB activity [142, 143] and suppresses proinflammatory cytokine production, including TNF $\alpha$ [144] and IL-6 [145]. In an allergic mouse model, exogenous adiponectin reduced AHR and inflammatory responses to an ovalbumin challenge, including a suppression of airway neutrophils [146]. Adiponectin levels have been shown to be reduced in asthma in some studies $[147,148]$ and reduced in subjects with low lung function [149]. Interestingly, some studies reporting that the relationship between adipokines and asthma only occurs in women [130, 147].

\section{Weight Loss Interventions in Obese Asthma}

Weight loss in obese asthma is associated with improved lung function, asthma severity and quality of life, and reduced asthma symptoms and medication usage [150-152]. A recent randomised weight 
loss intervention in overweight and obese asthmatic adults found that a 5-10\% weight loss was associated with a clinically significant improvement in asthma control and asthma-related quality of life [153], suggesting that a small weight loss may assist in the clinical management of this population. Only one randomised controlled weight loss trial has been conducted in adults with asthma, resulting in significant improvements in lung function and significantly fewer asthma exacerbations in the year following the intervention [152]. Few studies have examined the effects of weight loss on inflammation in asthma. Scott et al.[153] demonstrated that weight loss from the gynoid and arm regions is associated with reduced neutrophilic inflammation in asthmatic females. Dixon et al.[154] found an increase in bronchoalveolar lavage (BAL) lymphocytes, an increase in peripheral blood lymphocyte function, and a reduction in AHR in asthmatic adults who underwent surgically-induced weight loss. One recent uncontrolled weight loss study in obese adolescents, with and without asthma, reported significant improvements to plasma leptin, adiponectin and CRP, following 12 months of interdisciplinary therapy [150].

\section{Summary}

Weight loss interventions in asthma, via either dietary restriction or bariatric surgery, have clearly demonstrated that weight reduction improves lung function and symptoms. High quality randomised controlled trials are needed to understand the mechanisms driving this association; however, the efficacy of intervention is clear. With regard to antioxidants and fatty acids, there are a large number of studies, both epidemiological and mechanistic, that demonstrate a relationship between these nutrients and both immune responses and clinical asthma outcomes. However, the results of intervention trials are heterogeneous, with both positive and negative studies being reported [16, 60, $64,78,86,87,96]$. The most convincing data is from studies that have used manipulation of whole foods such as fruit and vegetables, those examining populations at an increased risk of oxidative stress, and studies that objectively measure antioxidant status. Progress in the field is limited by the 
paucity of this high quality, adequately powered, randomised controlled trials. Such trials are difficult to conduct due to the practical constraints and complexity of modifying dietary intake of whole foods and inducing weight loss in obese populations. However, considering the available evidence, it appears likely that this is the path to progress the field; as such trials are needed to obtain definitive evidence regarding the role of different dietary patterns or components.

\section{Abbreviations}

AA: Arachidonic acid;

AHR: Airway hyperresponsiveness;

BAL: Bronchoalveolar lavage;

BMI: Body mass index;

CRP: C-reactive protein;

DHA: Docosahexaenoic acid;

eNO: Exhaled nitric oxide;

EPA: Eicosapentaenoic acid;

$\mathrm{FEV}_{1}$ : Forced expiratory volume in one second;

FVC: Forced vital capacity;

ICS: Inhaled corticosteroid;

IFN: Interferon;

IgE: Immunoglobulin E;

IL: Interleukin;

LPS: Lipopolysaccharide;

LT: Leukotriene;

MDA: Malondialdehyde;

mRNA: Micro RNA; 
MUFA: Monounsaturated fatty acid;

PG: Prostaglandin;

PUFA: Polyunsaturated fatty acid;

ROS: Reactive oxygen species;

TAC: Total antioxidant capacity;

Th: T helper;

TLR: Toll-like receptor;

TNF- $\alpha$ : Tumor necrosis factor-alpha;

TX: Thromboxane

Conflict of Interest: The authors declare they have no conflict of interest to disclose. 


\section{References}

[1] GINA Executive Committee. Global Initiative for Asthma: Global strategy for asthma management and prevention, Updated 2010. www.ginasthma.com (accessed July 2011).

[2] Douwes J, Gibson P, Pekkanen J, Pearce N. Non-eosinophilic asthma: importance and possible mechanisms. Thorax 2002; 57: 643-8.

[3] Busse WW, Lemanske Jr RF. Asthma. New England Journal of Medicine 2001; 344: 350-62.

[4] Simpson JL, Scott RJ, Boyle MJ, Gibson PG. Inflammatory subtypes in asthma: Assessment and identification using induced sputum. Respirology 2006; 11: 54-61.

[5] Simpson JL, Grissell TV, Douwes J, Scott RJ, Boyle MJ, Gibson PG. Innate immune activation in neutrophilic asthma and bronchiectasis. Thorax 2007; 62: 211-8.

[6] Reed CE, Milton DK. Endotoxin-stimulated innate immunity: a contributing factor for asthma. J Allergy Clin Immunol 2001; 108: 157-66.

[7] Ólafsdottir IS, Gislason T, Thjodleifsson B, Olafsson Í, Gislason D, Jögi R, et al. C reactive protein levels are increased in non-allergic but not allergic asthma: a multicentre epidemiological study. Thorax 2005; 60: 451-4.

[8] Wood LG, Baines KJ, Fu J, Scott HA, Gibson PG. The neutrophilic inflammatory phenotype is associated with systemic inflammation in asthma. Chest 2012; 142: 86-93.

[9] Scott HA, Gibson PG, Garg ML, Wood LG. Airway Inflammation is Augmented by Obesity and Fatty Acids in Asthma. Eur Respir J 2011; 38: 594-602.

[10] Patel SD, Rajala MW, Rossetti L, Scherer PE, Shapiro L. Disulfide-Dependent Multimeric Assembly of Resistin Family Hormones. Science 2004; 304: 1154-8.

[11] Kaser S, Tatarczyk T, Stadlmayr A, Ciardi C, Ress C, Tschoner A, et al. Effect of obesity and insulin sensitivity on adiponectin isoform distribution. European Journal of Clinical Investigation 2008; 38: 827-34. 
[12] Chedevergne F, Le Bourgeois M, de Blic J, Scheinmann P. The role of inflammation in childhood asthma. Arch Dis Child 2000; 82: ii6-ii9.

[13] Halasz A, Cserhati E, Magyar P, KovÁCs M, Cseh K. Role of TNF- [alpha] and its 55 and 75 kDa receptors in bronchial hyperreactivity. Respir Med 2002; 96: 262-7.

[14] Boulet L-P, Franssen E. Influence of obesity on response to fluticasone with or without salmeterol in moderate asthma. Respir Med 2007; 101: 2240-7.

[15] Forno E, Lescher R, Strunk R, Weiss S, Fuhlbrigge A, Celedón JC. Decreased response to inhaled steroids in overweight and obese asthmatic children. J Allergy Clin Immunol 2011; 127: $741-9$

[16] Wood LG, Garg ML, Gibson PG. A high-fat challenge increases airway inflammation and impairs bronchodilator recovery in asthma. Journal of Allergy and Clinical Immunology 2011; 127: 1133-40.

[17] Masoli M, Fabian D, Holt S, Beasley R, for the Global Initiative for Asthma (GINA) Program. The global burden of asthma: executive summary of the GINA Dissemination Committee Report. Allergy 2004; 59: 469-78.

[18] Gibson PG, Henry RL, Shah S, Powell H, Wang H. Migration to a Western Country Increases Asthma Symptoms But Not Eosinophilic Airway Inflammation. Pediatric Pulmonology 2003; 36: 209-15.

[19] Hijazi N, Abalkhail B, Seaton A. Diet and childhood asthma in a society in transition: a study in urban and rural Saudi Arabia. Thorax 2000; 55: 775-9.

[20] Wickens K, Barry D, Friezema A, Rhodius R, Bone N, Purdie G, et al. Fast foods - are they a risk factor for asthma? Allergy 2005; 60: 1537-41.

[21] Carey OJ, Cookson JB, Britton J, Tattersfield AE. The effect of lifestyle on wheeze, atopy, and bronchial hyperreactivity in Asian and white children. Am J Respir Crit Care Med 1996; 154: 53740. 
[22] Huang SL, Lin KC, Pan WH. Dietary factors associated with physician-diagnosed asthma and allergic rhinitis in teenagers: analyses of the first Nutrition and Health Survey in Taiwan. Clin Exp Allergy 2001; 31: 259-64.

[23] Wood LG, Gibson PG. Dietary factors lead to innate immune activation in asthma. Pharmacology and Therapeutics 2009; 123: 37-53.

[24] Hu FB. Dietary pattern analysis: a new direction in nutritional epidemiology. Curr Opin Lipidol 2002; 13: 3-9.

[25] Wood LG, Scott HA, Garg ML, Gibson PG. Innate immune mechanisms linking non-esterified fatty acids and respiratory disease. Prog Lipid Res 2009; 48: 27-43.

[26] Margioris AN. Fatty acids and postprandial inflammation. Curr Opin Clin Nutr Metab Care 2009; 12: 129-37.

[27] Blackburn P, Després J-P, Lamarche B, Tremblay A, Bergeron J, Lemieux I, et al. Postprandial Variations of Plasma Inflammatory Markers in Abdominally Obese Men. Obesity 2006; 14: 1747-54. [28] Ström K, Janzon L, Mattisson I, Rosberg HE, Arborelius M. Asthma but not smoking-related airflow limitation is associated with a high fat diet in men: results from the population study "Men born in 1914", Malmö, Sweden. Monaldi Archives for Chest Disease 1996; 51: 16-21.

[29] Rodríguez-Rodríguez E, Perea JM, Jiménez AI, Rodríguez-Rodríguez P, López-Sobaler AM, Ortega RM. Fat intake and asthma in Spanish schoolchildren. Eur J Clin Nutr 2010; 64: 1065-71.

[30] Soutar A, Seaton A, Brown K. Bronchial reactivity and dietary antioxidants. Thorax 1997; 52: 166-70.

[31] Misso NLA, Brooks-Wildhaber J, Ray S, Vally H, Thompson PJ. Plasma concentrations of dietary and nondietary antioxidants are low in severe asthma. European Respiratory Journal 2005; 26: $257-64$. 
[32] Lee JY, Zhao L, Youn HS, Weatherill AR, Tapping R, Feng L, et al. Saturated Fatty Acid Activates but Polyunsaturated Fatty Acid Inhibits Toll-like Receptor 2 Dimerized with Toll-like Receptor 6 or 1. The Journal of Biological Chemistry 2004; 279.

[33] Lee JY, Hwang DA. The Modulation of Inflammatory Gene Expression by Lipids: Mediation through Toll-like Receptors. Molecules and Cells 2006; 21: 174-85.

[34] Baer DJ, Judd JT, Clevidence BA, Tracy RP. Dietary fatty acids affect plasma markers of inflammation in healthy men fed controlled diets: a randomized crossover study. Am J Clin Nutr 2004; 79: 969-73.

[35] Bellido C, López-Miranda J, Blanco-Colio LM, Pérez-Martínez P, Muriana FJ, Martín-Ventura JL, et al. Butter and walnuts, but not olive oil, elicit postprandial activation of nuclear transcription factor $\mathrm{\kappa B}$ in peripheral blood mononuclear cells from healthy men. Am J Clin Nutr 2004; 80: 148791.

[36] Huang S, Pan W. Dietary fats and asthma in teenagers: analyses of the first Nutrition and Health Survey in Taiwan (NAHSIT). Clinical and Experimental Allergy 2001; 31: 1875-80.

[37] Woods RK, Raven JM, Walters EH, Abramson MJ, Thien FCK. Fatty acid levels and risk of asthma in young adults. Thorax 2004; 59: 105-10.

[38] Field CJ, Johnson IR, Schley PD. Nutrients and their role in host resistance to infection. Journal of Leukocyte Biology 2002; 71: 16-32.

[39] Calder PC. Fat chance of immunomodulation. Immunology Today 1998; 19: 244-7.

[40] Miyake Y, Sasakiw S, Arakawaz M, Tanaka K, Murakami K, Ohya Y. Fatty acid intake and asthma symptoms in Japanese children: The Ryukyus Child Health Study. Clinical and Experimental Allergy 2008; 38: 1644-50.

[41] Bolte G, Kompauer I, Fobker M, Cullenz P, Keilk U, von Mutius E, et al. Fatty acids in serum cholesteryl esters in relation to asthma and lung function in children. Clinical and Experimental Allergy 2006; 36: 293-302. 
[42] Broadfield EC, McKeever TM, Whitehurst A, Lewis SA, Lawson N, Britton J, et al. A casecontrol study of dietary and erythrocyte membrane fatty acids in asthma. Clinical and Experimental Allergy 2004; 34: 1232-6.

[43] Schwartz J, Weiss ST. The relationship of dietary fish intake to level of pulmonary function in the first National Health and Nutrition Survey (NHANES I). Eur Respir J 1994; 7: 1821-4.

[44] de Luis DA, Armentia A, Aller R, Asensio A, Sedano E, Izaola O, et al. Dietary intake in patients with asthma: a case control study. Nutrition 2005; 21: 320-4.

[45] Mihrshahi S, Peat JK, Webb K, Oddy W, Marks GB, Mellis CM. Effect of omega-3 fatty acid concentrations in plasma on symptoms of asthma at 18 months of age. Pediatr Allergy Immunol 2004; 15: 517-22.

[46] Yu G, Kjellman NI, Bjorksten B. Phospholipid fatty acids in cord blood: family historyand development of allergy. Acta Paediatr 1996; 85: 679-83.

[47] Hodge L, Salome CM, Peat JK, Haby MM, Xuan W, Woolcock AJ. Consumption of oily fish and childhood asthma risk. The Medical journal of Australia 1996; 164: 137-40.

[48] Peat JK, Salome CM, Woolcock AJ. Factors associated with bronchial hyperresponsiveness in Australian adults and children. Eur Respir J 1992; 5: 921-9.

[49] Chatzi L, Torrent M, Romieu I, Garcia-Esteban R, Ferrer C, Vioque J, et al. Diet, wheeze, and atopy in school children in Menorca, Spain. Pediatr Allergy Immunol 2007; 18: 480-5.

[50] Tabak C, Wijga AH, de Meer G, Janssen NA, Brunekreef B, Smit HA. Diet and asthma in Dutch school children (ISAAC-2). Thorax 2006; 61: 1048-53.

[51] Laerum BN, Wentzel-Larsen T, Gulsvik A, Omenaas E, Gislason T, Janson C, et al. Relationship of fish and cod oil intake with adult asthma. Clin Exp Allergy 2007; 37: 1616-23.

[52] Woods RK, Raven JM, Walters EH, Abramson MJ, Thien FC. Fatty acid levels and risk of asthma in young adults. Thorax 2004; 59: 105-10. 
[53] Leichsenring M, Kochsiek U, Paul K. (n-6)-Fatty acids in plasma lipids of children with atopic bronchial asthma. Pediatr Allergy Immunol 1995; 6: 209-12.

[54] Newson RB, Shaheen SO, Henderson AJ, Emmett PM, Sherriff A, Calder PC. Umbilical cord and maternal blood red cell fatty acids and early childhood wheezing and eczema. J Allergy Clin Immunol 2004; 114: 531-7.

[55] Broadfield EC, McKeever TM, Whitehurst A, Lewis SA, Lawson N, Britton J, et al. A casecontrol study of dietary and erythrocyte membrane fatty acids in asthma. Clin Exp Allergy 2004; 34: 1232-6.

[56] Bolte G, Kompauer I, Fobker M, Cullen P, Keil U, Mutius E, et al. Fatty acids in serum cholesteryl esters in relation to asthma and lung function in children. Clin Exp Allergy 2006; 36: 293-302.

[57] McKeever TM, Lewis SA, Cassano PA, Ocke M, Burney P, Britton J, et al. The relation between dietary intake of individual fatty acids, FEV1 and respiratory disease in Dutch adults. Thorax 2008; 63: 208-14.

[58] Troisi RJ, Willett WC, Weiss ST, Trichopoulos D, Rosner B, Speizer FE. A prospective study of diet and adult-onset asthma. Am J Respir Crit Care Med 1995; 151: 1401-8.

[59] Fluge O, Omenaas E, Eide G, Gulsvik A. Fish consumption and respiratory symptoms among young adults in a Norwegian community. Eur Respir J 1998; 12: 336-40.

[60] Woods RK, Thien FC, Abramson MJ. Dietary marine fatty acids (fish oil) for asthma in adults and children. Cochrane Database Syst Rev 2002; CD001283.

[61] Schwartz J, Weiss ST. Dietary factors and their relation to respiratory symptoms. The Second National Health and Nutrition Examination Survey. Am J Epidemiol 1990; 132: 67-76.

[62] Kiefte-de Jong JC, de Vries JH, Franco OH, Jaddoe VWV, Hofman A, Raat H, et al. Fish Consumption in Infancy and Asthma-like Symptoms at Preschool Age. Pediatrics 2012; 130: 1060-8. 
[63] Wood LG, Hazlewood LC, Foster PS, Hansbro PM. Lyprinol reduces inflammation and improves lung function in a mouse model of allergic airways disease. Clin Exp Allergy 2010; 40: 1785-93.

[64] Emelyanov A, Fedoseev G, Krasnoschekova O, Abulimity A, Trendeleva T, Barnes PJ. Treatment of asthma with lipid extract of New Zealand green-lipped mussel: a randomised clinical trial. Eur Respir J 2002; 20: 596-600.

[65] Michalsen AL, N, Pithan C, Knoblauch NTM, Moebus S, Kannenberg F, Binder L, et al. Mediterranean diet has no effect on markers of inflammation and metabolic risk factors in patients with coronary artery disease. Eur J Clin Nutr 2006; 60: 478-85.

[66] Miyamoto S, Miyake Y, Sasaki S, Tanaka K, Ohya Y, Matsunaga I, et al. Fat and fish intake and asthma in Japanese women: baseline data from the Osaka Maternal and Child Health Study. The International Journal of Tuberculosis and Lung Disease 2007; 11: 103-9.

[67] Tabak C, Wijga AH, de Meer G, Janssen NAH, Brunekreef B, Smit HA. Diet and asthma in Dutch school children (ISAAC-2). Thorax 2006; 61: 1048-53.

[68] Park C-S, Kim T-B, Lee K-Y, Moon K-A, Bae Y-J, Jang MK, et al. Increased oxidative stress in the airway and development of allergic inflammation in a mouse model of asthma. Ann Allergy Asthma Immunol 2009; 103: 238-47.

[69] Hulsmann AR, Raatgeep HR, den Hollander JC, Stijnen T, Saxena PR, Kerrebijn KF, et al. Oxidative epithelial damage produces hyperresponsiveness of human peripheral airways. Am J Respir Crit Care Med 1994; 149: 519-25.

[70] Sanders SP, Zweier JL, Harrison SH, Trush MA, Rembish SJ, Liu MC. Spontaneous Oxygen Radical Produdion at Sites of Antigen Challenge in Allergic Subjects. Am J Respir Crit Care Med 1995; 151: 1725-33. 
[71] Vachier I, Chanez P, Le Doucen C, Damon M, Descomps B, Godard P. Enhancement of reactive oxygen species formation in stable and unstable asthmatic patients. Eur Respir J 1994; 7: 1585-92.

[72] Wood LG, Garg ML, Blake RJ, Garcia-Caraballo S, Gibson PG. Airway and circulating levels of carotenoids in asthma and healthy controls. Journal of the American College of Nutrition 2005; 24: 448-55.

[73] Shaheen SO, Sterne JAC, Thompson RL, Songhurst CA, Margetts BM, Burney PGJ. Dietary Antioxidants and Asthma in Adults: Population-based Case-Control Study. American Journal of Respiratory and Critical Care Medicine 2001; 164: 1823-8.

[74] Fabian E, Pölöskey P, Kósa L, Elmadfa I, Réthy LA. Activities of Antioxidant Enzymes in Relation to Oxidative and Nitrosative Challenges in Childhood Asthma. Journal of Asthma 2011; 48: $351-7$.

[75] Seaton A, Godden DJ, Brown K. Increase in asthma: a more toxic environment or a more susceptible population? Thorax 1994; 49: 171-4.

[76] Cook DG, Carey IM, Whincup PH, Papacosta O, Chirico S, Bruckdorfer KR, et al. Effect of fresh fruit consumption on lung function and wheeze in children. Thorax 1997; 52: 628-33.

[77] Carey IM, Strachan DP, Cook DG. Effects of Changes in Fresh Fruit Consumption on Ventilatory Function in Healthy British Adults. American Journal of Respiratory and Critical Care Medicine 1998; 158: 728-33.

[78] Wood LG, Garg ML, Smart JM, Scott HA, Barker D, Gibson PG. Manipulating antioxidant intake in asthma: a randomized controlled trial. Am J Clin Nutr 2012; 96: 534-43.

[79] Thyagarajan B, Meyer KA, Smith LJ, Beckett WS, Williams OD, Gross MD, et al. Serum carotenoid concentrations predict lung function evolution in young adults: the Coronary Artery Risk Development in Young Adults (CARDIA) Study. American Journal of Clinical Nutrition 2011; 94: 1211-8. 
[80] Guénégou A, Leynaert B, Pin I, Le Moël G, Zureik M, Neukirch F. Serum carotenoids, vitamins A and E, and 8 year lung function decline in a general population. Thorax 2006; 61: 320-6.

[81] Grievink L, Smit HA, Ocké MC, van ‘t Veer P, Kromhout D. Dietary intake of antioxidant (pro)-vitamins, respiratory symptoms and pulmonary function: the MORGEN study. Thorax 1998; 53: 166-71.

[82] Hu G, Cassano PA. Antioxidant Nutrients and Pulmonary Function: The Third National Health and Nutrition Examination Survey (NHANES III). American Journal of Epidemiology 2000; 151: 975-81.

[83] Rubin RN, Navon L, Cassano PA. Relationship of Serum Antioxidants to Asthma Prevalence in Youth. American Journal of Respiratory and Critical Care Medicine 2004; 169: 393-8.

[84] Harik-Khan RI, Muller DC, Wise RA. Serum Vitamin Levels and the Risk of Asthma in Children. American Journal of Epidemiology 2004; 159: 351-7.

[85] Wood LG, Garg ML, Powell H, Gibson PG. Lycopene-rich treatments modify noneosinophilic airway inflammation in asthma: Proof of concept. Free Radical Research 2008; 42: 94-102.

[86] Hazlewood LC, Wood LG, Hansbro PM, Foster PS. Dietary lycopene supplementation suppresses Th2 responses and lung eosinophilia in a mouse model of allergic asthma. The Journal of Nutritional Biochemistry 2011; 22: 95-100.

[87] Checkley W, West Jr KP, Wise RA, Baldwin MR, Wu L, LeClerq SC, et al. Maternal Vitamin A Supplementation and Lung Function in Offspring. New England Journal of Medicine 2010; 362: 1784-894.

[88] Gilliland FD, Berhane KT, Li Y-F, Gauderman WJ, McConnell R, Peters J. Children’s Lung Function and Antioxidant Vitamin, Fruit, Juice, and Vegetable Intake. American Journal of Epidemiology 2003; 158: 576-84.

[89] McKeever TM, Lewis SA, Smit HA, Burney P, Cassano PA, Britton J. A multivariate analysis of serum nutrient levels and lung function. Respiratory Research 2008; 9: 67. 
[90] Slade R, Crissman K, Norwood J, Hatch G. Comparison of Antioxidant Substances in Bronchoalveolar Lavage Cells and Fluid from Humans, Guinea Pigs, and Rats. Experimental Lung Research 1993; 19: 469-84.

[91] Ford ES, Mannino DM, Redd SC. Serum Antioxidant Concentrations Among U.S. Adults with Self-Reported Asthma. Journal of Asthma 2004; 41: 179-87.

[92] Grievink L, Zijlstra AG, Ke X, Brunekreef B. Double-Blind Intervention Trial on Modulation of Ozone Effects on Pulmonary Function by Antioxidant Supplements. American Journal of Epidemiology 1999; 149: 306-14.

[93] Romieu I, Sienra-Monge JJ, Ramirez-Aguilar M, Tellez-Rojo MM, Moreno-Macias H, ReyesRuiz NI, et al. Antioxidant Supplementation and Lung Functions among Children with Asthma Exposed to High Levels of Air Pollutants. American Journal of Respiratory and Critical Care Medicine 2002; 166: 703-9.

[94] Haines DD, Varga B, Bak I, Juhasz B, Mahmoud FF, Kalantari H, et al. Summative Interaction between Astaxanthin, Ginkgo biloba Extract (EGb761) and Vitamin C in Suppression of Respiratory Inflammation: A Comparison with Ibuprofen. Phytotherapy Research 2011; 25: 128-36.

[95] Biltagi MA, Baset AA, Bassiouny M, Kasrawi MA, Attia M. Omega-3 fatty acids, vitamin C and Zn supplementation in asthmatic children: a randomized self-controlled study. Acta Paediatrica 2009; 98: 737-42.

[96] Kaur B, Rowe BH, Arnold E. Vitamin C supplementation for asthma. Cochrane Database of Systematic Reviews 2009, Issue 1. Art. No.: CD000993. DOI: 10.1002/14651858.CD000993.pub3. 2009.

[97] Bakkeheim E, Mowinckel P, Carlsen KH, Burney P, Carlsen KCL. Altered oxidative state in schoolchildren with asthma and allergic rhinitis. Pediatric Allergy and Immunology 2011; 22: 17885. 
[98] Bodner C, Godden D, Brown K, Little J, Ross S, Seaton A. Antioxidant intake and adult-onset wheeze: a case \pm control study. European Respiratory Journal 1999; 13: 22-30.

[99] Devereux G, Turner SW, Craig LCA, McNeill G, Martindale S, Harbour PJ, et al. Low Maternal Vitamin E Intake during Pregnancy Is Associated with Asthma in 5-Year-Old Children. American Journal of Respiratory and Critical Care Medicine 2006; 174: 499-507.

[100] Litonjua AA, Rifas-Shiman SL, Ly NP, Tantisira KG, Rich-Edwards JW, Camargo Jr CA, et al. Maternal antioxidant intake in pregnancy and wheezing illnesses in children at $2 \mathrm{y}$ of age. The American Journal of Clinical Nutrition 2006; 84: 903-11.

[101] Fogarty A, Lewis S, Weiss S, Britton J. Dietary vitamin E, IgE concentrations, and atopy. The Lancet 2000; 356: 1573-4.

[102] Feuerer M, Herrero L, Cipolletta D, Naaz A, Wong J, Nayer A, et al. Lean, but not obese, fat is enriched for a unique population of regulatory $\mathrm{T}$ cells that affect metabolic parameters. Nat Med 2009; 15: 930-9.

[103] Deiuliis J, Shah Z, Shah N, Needleman B, Mikami D, Narula V, et al. Visceral adipose inflammation in obesity is associated with critical alterations in tregulatory cell numbers. PLoS One 2011; 6: e16376.

[104] Wagner JG, Jiang Q, Harkema JR, Ames BN, Illek B, Roubey RA, et al. $\gamma$-Tocopherol prevents airway eosinophilia and mucous cell hyperplasia in experimentally induced allergic rhinitis and asthma. Clinical and Experimental Allergy 2007; 38: 501-11.

[105] Pearson PJ, Lewis SA, Britton J, Fogarty A. Vitamin E supplements in asthma: a parallel group randomised placebo controlled trial. Thorax 2004; 59: 652-6.

[106] Beuther DA, Sutherland ER. Overweight, Obesity, and Incident Asthma: A Meta-analysis of Prospective Epidemiologic Studies. Am J Respir Crit Care Med 2007; 175: 661-6.

[107] Flaherman V, Rutherford G. A meta-analysis of the effect of high weight on asthma. Arch Dis Child 2006; 91: 334-9. 
[108] Dixon AE, Shade DM, Cohen RI, Skloot GS, Holbrook JT, Smith LJ, et al. Effect of Obesity on Clinical Presentation and Response to Treatment in Asthma. J Asthma 2006; 43: 553-8.

[109] Thomson CC, Clark S, Camargo Jr CA, on Behalf of the MARC Investigators. Body Mass Index and Asthma Severity Among Adults Presenting to the Emergency Department. Chest 2003; 124: 795-802.

[110] Visness CM, London SJ, Daniels JL, Kaufman JS, Yeatts KB, Siega-Riz A-M, et al. Association of Childhood Obesity With Atopic and Nonatopic Asthma: Results From the National Health and Nutrition Examination Survey 1999-2006. Journal of Asthma 2010; 47: 822-9.

[111] Kattan M, Kumar R, Bloomberg G, Mitchell H, Calatroni A, etc. Asthma control, adiposity, and adipokines among inner-city adolescents. J Allergy Clin Immunol 2010; 125: 584-92.

[112] Lazarus R, Colditz G, Berkey CS, Speizer FE. Effects of body fat on ventilatory function in children and adolescents: Cross-sectional findings from a random population sample of school children. Pediatric Pulmonology 1997; 24: 187-94.

[113] Loebroks A, Apfelbacher CJ, Amelang M, Stürmer T. Obesity and Adult Asthma: Potential Effect Modification by Gender, But Not by Hay Fever. Annals of Epidemiology 2008; 18: 283-9.

[114] Beckett WS, Jacobs Jr DR, Yu X, Iribarren C, Williams OD. Asthma is Associated with Weight Gain in Females but Not Males, Independent of Physical Activity. American Journal of Respiratory and Critical Care Medicine 2001; 164: 2045-50.

[115] Visness CM, London SJ, Daniels JL, Kaufman JS, Yeatts KB, Siega-Riz A-M, et al. Association of childhood obesity with atopic and nonatopic asthma: results from the National Health and Nutrition Examination Survey 1999-2006. J Asthma 2010; 47: 822-9.

[116] Salome CM, King GG, Berend N. Physiology of obesity and effects on lung function. J Appl Physiol 2010; 108: 206-11.

[117] King GG, Brown NJ, Diba C, Thorpe CW, Muñoz P, Marks GB, et al. The effects of body weight on airway calibre. Eur Respir J 2005; 25: 896-901. 
[118] Jensen ME, Collins CE, Gibson PG, Wood LG. The Obesity Phenotype in Children with Asthma. Paediatric Respiratory Reviews 2011; 12: 152-9.

[119] Sood A, Ford ES, Camargo Jr CA. Association between leptin and asthma in adults. Thorax 2006; 61: 300-5.

[120] Sood A, Cui X, Qualls C, Beckett WS, Gross MD, Steffes MW, et al. Association between asthma and serum adiponectin concentration in women. Thorax 2008; 63: 877-82.

[121] Lessard A, Turcotte H, Cormier Y, Boulet L-P. Obesity and Asthma: A Specific Phenotype? Chest 2008; 134: 317-23.

[122] Sutherland TJT, Cowan JO, Young S, Goulding A, Grant AM, Williamson A, et al. The association between obesity and asthma: interactions between systemic and airway inflammation. Am J Respir Crit Care Med 2008; 178: 469-75.

[123] Lang JE, Feng H, Lima JJ. Body Mass Index-Percentile and Diagnostic Accuracy of Childhood Asthma. J Asthma 2009; 46: 291-9.

[124] Delgoffe GM, Pollizzi KN, Waickman AT, Heikamp E, Meyers DJ, Horton MR, et al. The kinase mTOR regulates the differentiation of helper $\mathrm{T}$ cells through the selective activation of signaling by mTORC1 and mTORC2. Nat Immunol 2011; 12: 295-303.

[125] van Veen IH, ten Brinke A, Sterk PJ, Rabe KF, Bel EH. Airway inflammation in obese and nonobese patients with difficult-to-treat asthma. Allergy 2008; 63: 570-4.

[126] Berg CM, Thelle DS, Rosengren A, Lissner L, Torén K, Olin A-C. Decreased Fraction of Exhlaed Nitric Oxide in Obese Subjects With Asthma Symptoms. Chest 2011; 139: 1109-16.

[127] Telenga ED, Tideman SW, Kerstjens HAM, ten Hacken NHT, Timens W, Postma DS, et al. Obesity in asthma: more neutrophilic inflammation as a possible explanation for a reduced treatment response. Allergy 2012; 67: 1060-8.

[128] Ilavská S, Horváthová M, Szabová M, Nemessányi T, Jahnová E, Tulinská J, et al. Association between the human immune response and body mass index. Human Immunology 2012; 73: 480-5. 
[129] Guler N, Kirerleri E, Ones U, Tamay Z, Salmayenli N, Darendeliler F. Leptin: does it have any role in childhood asthma? J Allergy Clin Immunol 2004; 114: 254-9.

[130] Sood A, Ford ES, Camargo CA, Jr. Association between leptin and asthma in adults. Thorax 2006; 61: 300-5.

[131] Gurkan F, Atamer Y, Ece A, Kocyigit Y, Tuzun H, Mete N. Serum leptin levels in asthmatic children treated with an inhaled corticosteroid. Ann Allergy Asthma Immunol 2004; 93: 277-80.

[132] Larochelle J, Freiler J, Dice J, Hagan L. Plasma resistin levels in asthmatics as a marker of disease state. J Asthma 2007; 44: 509-13.

[133] Bouloumie A, Marumo T, Lafontan M, Busse R. Leptin induces oxidative stress in human endothelial cells. FASEB J 1999; 13: 1231-8.

[134] Silswal N, Singh AK, Aruna B, Mukhopadhyay S, Ghosh S, Ehtesham NZ. Human resistin stimulates the pro-inflammatory cytokines TNF-alpha and IL-12 in macrophages by NF-kappaBdependent pathway. Biochem Biophys Res Commun 2005; 334: 1092-101.

[135] Zhao T, Hou M, Xia M, Wang Q, Zhu H, Xiao Y, et al. Globular adiponectin decreases leptininduced tumor necrosis factor-alpha expression by murine macrophages: involvement of cAMP-PKA and MAPK pathways. Cell Immunol 2005; 238: 19-30.

[136] Bokarewa M, Nagaev I, Dahlberg L, Smith U, Tarkowski A. Resistin, an adipokine with potent proinflammatory properties. J Immunol 2005; 174: 5789-95.

[137] Caldefie-Chezet F, Poulin A, Tridon A, Sion B, Vasson MP. Leptin: a potential regulator of polymorphonuclear neutrophil bactericidal action? J Leukoc Biol 2001; 69: 414-8.

[138] Mancuso P, Huffnagle GB, Olszewski MA, Phipps J, Peters-Golden M. Leptin corrects host defense defects after acute starvation in murine pneumococcal pneumonia. Am J Respir Crit Care Med 2006; 173: 212-8.

[139] Shore SA, Schwartzman IN, Mellema MS, Flynt L, Imrich A, Johnston RA. Effect of leptin on allergic airway responses in mice. J Allergy Clin Immunol 2005; 115: 103-9. 
[140] Arita Y, Kihara S, Ouchi N, Takahashi M, Maeda K, Miyagawa J, et al. Paradoxical decrease of an adipose-specific protein, adiponectin, in obesity. Biochem \& Biophys Res Comm 1999; 257: 79-83.

[141] Bruun JM, Lihn AS, Verdich C, Pedersen SB, Toubro S, Astrup A, et al. Regulation of adiponectin by adipose tissue-derived cytokines: in vivo and in vitro investigations in humans. Am J Physiol Endocrinol Metab 2003; 285: E527-33.

[142] Yamaguchi N, Argueta JG, Masuhiro Y, Kagishita M, Nonaka K, Saito T, et al. Adiponectin inhibits Toll-like receptor family-induced signaling. FEBS Lett 2005; 579: 6821-6.

[143] Neumeier M, Weigert J, Schaffler A, Wehrwein G, Muller-Ladner U, Scholmerich J, et al. Different effects of adiponectin isoforms in human monocytic cells. J Leukoc Biol 2006; 79: 803-8. [144] Yokota T, Oritani K, Takahashi I, Ishikawa J, Matsuyama A, Ouchi N, et al. Adiponectin, a new member of the family of soluble defense collagens, negatively regulates the growth of myelomonocytic progenitors and the functions of macrophages. Blood 2000; 96: 1723-32.

[145] Wolf AM, Wolf D, Rumpold H, Enrich B, Tilg H. Adiponectin induces the anti-inflammatory cytokines IL-10 and IL-1RA in human leukocytes. Biochem Biophys Res Commun 2004; 323: 6305.

[146] Shore SA, Terry RD, Flynt L, Xu A, Hug C. Adiponectin attenuates allergen-induced airway inflammation and hyperresponsiveness in mice. J Allergy Clin Immunol 2006; 118: 389-95.

[147] Sood A, Cui X, Qualls C, Beckett WS, Gross MD, Steffes MW, et al. Association between asthma and serum adiponectin concentration in women. Thorax 2008; 63: 877-82.

[148] Nagel G, Koenig W, Rapp K, Wabitsch M, Zoellner I, Weiland SK. Associations of adipokines with asthma, rhinoconjunctivitis, and eczema in German schoolchildren. Pediatric Allergy \& Immunology 2009; 20: 81-8. 
[149] Thyagarajan B, Jacobs DR, Jr., Smith LJ, Kalhan R, Gross MD, Sood A. Serum adiponectin is positively associated with lung function in young adults, independent of obesity: the CARDIA study. Respir Res 11: 176.

[150] da Silva PL, de Mello MT, Cheik NC, Sanches PL, Correia FA, de Piano A, et al. Interdisciplinary therapy improves biomarkers profile and lung function in asthmatic obese adolescents. Pediatr Pulmonol 2012; 47: 8-17.

[151] Boulet L-P, Turcotte H, Martin J, Poirier P. Effect of bariatric surgery on airway response and lung function in obese subjects with asthma. Respiratory Medicine 2012; 106: 651-60.

[152] Stenius-Aarniala B, Poussa T, Kvarnström J, Grönlund E-L, Ylikahri M, Mustajoki P. Immediate and long term effects of weight reduction in obese people with asthma: randomised controlled study. BMJ 2000; 320: 827-32.

[153] Sheridan PA, Paich HA, Handy J, Karlsson EA, Hudgens MG, Sammon AB, et al. Obesity is associated with impaired immune response to influenza vaccination in humans. Int J Obes 2011; 36: 1072-7.

[154] Dixon AE, Pratley RE, Forgione PM, Kaminsky DA, Whittaker-Leclair LA, Griffes LA, et al. Effects of obesity and bariatric surgery on airway hyperresponsiveness, asthma control, and inflammation. J Allergy Clin Immunol 2011; 128: 508-15. 